Egypt, that entered the Piræus: at various times also, and particularly in the year of the city 389 (before the building of the aqueducts), the Roman capital was visited with the same calamity: but this is nothing to the fearful visitations with which all Europe was afflicted during the 14th, 15th, 16th, and I 7 th centuries.

The last appearance of the Plague in Europe was in 1719, when it was introduced into Marseilles by a ship that had been refused admittance into the port of Cagliari in Sardinia. Even then its course might probably have been stopped, had its malignant nature been recognised soon enough; but this was not the case, and more than 90,000 persons were killed by it. Here we have a clear proof of the value of preventive measures. Sardinia was saved because the king refused the admission of the ship into the port of Cagliari; Marseilles was ravaged because a like precaution was not taken.

In England we are accustomed to manage affairs in a less official manner than they are managed abroad, and the result is that improvements, although more difficult of introduction, are often more surely brought about with us than with our neighbours. It is certainly not because we are less hygienic in our habits than other nations, that we have so few books on hygiene, or that our Medical Schools have not looked upon it as a sister science with Medicine; but because it seemed to take no special line, and because it seemed to be so much everybody's business: now, however, since the formation of the General Board of Health and the Registrar-General's office, such a mass of information with regard to the statistics and to the causes of disease has been obtained, that it seems necessary to make a special study of this science, and no longer to allow it to be taught accidentally as an appendage to Pathology or Therapeutics.

W. H. CORFIELD

\section{SCIENCE EDUCATION IN GERMANY}

\section{I.-THE GERMAN UNIVERSITY SYSTEM}

THE most striking point of difference between the condition of science teaching in Germany and in England lies in the great facilities and encouragements which, in the former country, are given to the study of science in its highest development. In primary education, we are in England probably doing as much or more in the way of encouraging the teaching of elementary science as is being done in Germany, or elsewhere. It is our richly endowed Universities which have as yet failed to play the important part in this essential feature of modern education which, from their position and means, we have a right to expect them to do, whilst other less wealthy Colleges and educational establishments, quite as capable of giving the highest scientific instruction, have to battle with almost overwhelming difficulties, Government, on the other hand, true to its supposed function of simply assisting those who cannot help themselves, only gives pecuniary aid towards the science instruction of the working classes; and, with a singular want of foresight, provides no systematic means of training the teachers, * who are left to pick up their education as best they may.

* The few Queen's prizes and other exhibitions for instruction in the Royal School of Mines cannot in any respect be considered as a system of science edication for teachers.
The university system of Germany is now so different in character from that of England, that it is difficuit to believe that these institutions, of the same age and standing, were founded on the same type, and perhaps equally so to explain how they came to be so essentially different. The cause of this difference appears, however, to me to lie less in the necessarily varying nature of national character and requirements, than in the simple fact that in Oxford and Cambridge the system of colleges founded originally as benefactions to religious societies by private donors, and still retaining a party and religious character, has swamped (or nearly so) the university; and that the college tuition interferes with, and is indeed often absolutely opposed to, that of the proper educating body which it was intended only to supplement. In Germany the college system does not exist, and the university has always remained supreme in its locality; it knows of no interference, religious or otherwise, in its own sphere; its system of education is regulated according to one prixciple, and one spirit of emulation pervades the whole staff of teachers.

It is singular to notice that the German universities, which are all of them Government institutions, every professor being a civil servant of the Crown, taking the oaths and receiving salary and pension, do not suffer from what we are apt to consider the deadening influence of Government service. On the contrary, this system now holds, and has always contained, the highest and best intellectual life of the nation, replete with energy both as regards teaching power and original research. This may be explained by the fact that although the universities arc State institutions, yet they are practically free as regards their internal government. Each Professor teaches as he thinks best, and Ministerial interference with the regulations of the Senate is of the rarest occurrence. In another point of view, it is well to compare the Government universities of what we Englishmen are even yet too apt to consider as the despotic and illiberal German powers with our free (!) universities. In Germany all, from prince to peasant, who choose, can and do come to the university, provided they bring certificates of having passed the exit examination of their gymnasium, as a proof of due qualification to benefit from the university instruction. Thus, the small government of Baden supports two universities, to the benefits of which persons of all classes, of all religious denominations, and natives of all countries are permitted to enter, without limitation of number, without religious test of any kind, and for the payment of ridiculously low fees. Can we say that our universities are as free? or that we in England possess any other institutions which fulfil for us the duties of these High Schools for the German people?

The university system of Germany has most certainly succeeded in stimulating intellectual activity, and fostering a spirit of original inquiry amongst the teachers, and thus creating a true profession of learned men. On the other hand, it offers sufficient inducement to aspiring students to devote themselves to special pursuits, and raise their aims to something higher than mere "Brodstudien," by opening out to them a path, often arduous and rugged, by which a man of ability may rise, from privat-docent and extraordinary professor, to the highest position of university eminence. This free infusion of 
new blood into the teaching staff is one great secret of the vitality of the German system ; another, certainly, is the well-known principle of "Lern und Lehr-Freiheit." The professor is, on the one hand, perfectly free to treat his subject as he thinks best; and the student has a free choice amongst the various teachers of the particular department of study to which he may devote himself. Can our system, with its far larger pecuniary means, with its hundreds of scholarships and non-resident fellowships, compare in these respects, as inducing men to devote themselves to study, with the German universities?

There is no doubt that the secondary school education in England is inferior, in breadth and completeness, to the strict gymnasial system of Germany. Hence our universities are obliged to act more as finishing schools, occupied with raising the general level instead of carrying out the more scientific, higher, and more original studies which form the professional side of education, the "Fach-studien" which constitute the essential elements of the German system.

In even the smallest German university the four faculties of Philosophy (or art studies), Law, Medicine, and Theology exist in active operation. In the first of these faculties, all those students enter who desire to study either Philology and the cognate subjects, Historical science, the Mathematical sciences, or any of the various branches of Physical science.

The Law students confine themselves to their own Faculty where the theory of the profession is brought before them in a scientific order before they begin to learn the practice of the law.

In Medicine, the danger of a knowledge acquired by practice alone, and the necessity of a scientific education, are too patent to have escaped attention even in England; and hence the establishment of our numerous medical schools, attached to large hospitals. In Germany, such medical schools unconnected with other faculties are unknown; medicine forms an essential feature of every university system ; and even comparatively small towns, as Heidelberg and Würtzburg, have their large and well-regulated hospitals, and are able to draw to themselves such men as Helmholtz and Kölliker. On the advantage of association of medical students with those pursuing other studies it is needless to enlarge.

In Theology there are frequently two faculties, one based upon Catholic and the other upon Protestant principles; these are found to work satisfactorily, and in Germany all who enter either Church must have at any rate gone through a regular course of theological instruction.

Another grand point in which the German university excels the English is the much larger proportion of qualified teachers which we find in the former.

As an example of the enormous teaching power in Germany, let us take the Philosophical Faculty in the University of Berlin. Here four professors and five other lecturers give twenty distinct courses each semestre (half year) in the science of Chemistry alone, including several on systematic chemistry, the history of chemistry, the chemical foundations of geology, metallurgy, pharmacy, \&c. Under the head of Physics the following ten distinct courses were given by seven Professors during the summer semestre of
I 868 , and, in addition, a physical laboratory is conducted by Prof. Magnus :-

\begin{tabular}{|c|c|c|}
\hline & $\begin{array}{c}\text { Hou } \\
\text { week }\end{array}$ & $\begin{array}{l}\text { Hours } \\
\text { weekly }\end{array}$ \\
\hline $\mathrm{cs}$ & & Phys \\
\hline & . 5 & eory of Heat \\
\hline coustics. & & Hydrography \\
\hline Capillary Theory. & & Physical Geography. \\
\hline heory of Light and of & f Optical & Instruction in Methods of \\
\hline Instruments & & Physical and Geo \\
\hline
\end{tabular}

In the Biological subjects, ten professors and lecturers gave twenty-one courses, theoretical and practical. In Classics and allied subjects, thirteen professors and eight lecturers gave twenty-three courses; and on other linguistic subjects, eighteen professors and lecturers gave forty courses. In Mathematics, six professors and lecturers gave thirteen courses. In what we should call Mental and Moral Philosophy,including pædagogy, eleven professors and lecturers gave nineteen courses. In Economic and Agricultural sciences, seven professors and lecturers gave twelve courses. In History and Geography, nine professors and lecturers gave thirteen courses. In Belles-lettres and the Fine Arts, seven professors gave ten courses. It must be remembered that all the courses enumerated above belong to the Faculty of Arts (Philosophische Facultät), and are exclusive of the three other faculties, in each of which the subjects are represented in a similar proportion.

It is, of course, impossible for us in England to attempt to set up a system on this scale; but we cannot be too fully aware of the miserably insufficient way in which these studies are represented in our country; and we may rest assured that the existence, in due proportions, of a plurality of teachers is an indispensable pre-requisite for both breadth and depth of study. Where only one teacher is charged with one leading branch of study, it is barely within his power to provide the systematic teaching necessary for pass-men; whereas if, as in German universities, several teachers lecture concurrently on subdivisions of a subject, the more advanced students have the opportunity of studying more thoroughly some one section of their science. The teachers are also induced, by the opportunity of lecturing on special subjects, to engage in profounder investigations; and thus that other aim of university institutions - the advancement of science and the promotion of a learned class-is furthered. This is a consideration-at least, however, so far as England is concerned-for a remote future: it is sufficient to insist on the necessity of this plurality of teachers in order to ensure really effective teaching. The same subdivision of each subject appears in all the German universities. Thus in Göttingen, by no means one of the recently founded universities, and not subject in any special degree to those influences which have so remarkably fostered the growth of the sciences of observation and experiment, we find the following courses given in $1868:-$

In Göttingen, Chemistry is (against the usage in Germany) attached to the Medical Faculty; there are, however, three divisions-the general, the physiological, and the agricultural. In the first, we find Professor Wöhler, with four skilled assist. ants; two of these being also professors. In the physiological division is another professor, with one assistant; and in the agricultural division, is one professor and one assistant. There are, further, four laboratory servants.

Professor Wöhler delivers the principal course of lectures on systematic chemistry. His assistants lecture on special branches. 
The whole staff directs the laboratory; and over and above these are the two professors of physiological and agricultural chemistry, who conduct their own laboratories.

In Physics, Professor Weber and his assistants, Professors Listing and Kohlrausch, conduct an excellent physical laboratory, and lecture on the several branches of physics-systematic physics, optics, electricity, \&c., light and heat, meteorology. Professor Ulrich treats of hydrostatics and hydraulics.

In Natural History, Professor Keferstein lectures on comparative anatomy, and performs zootomical demonstrations in the Zoological Museum during eight hours weekly to the students; for four hours weekly the Museum is open to the public, when the same Professor is present to conduct demonstrations. Two professors lecture on Botany (each six houtrs weekly), and combine with their lectures excursions and demonstrations in the Botanical Garden ; there is also a third assistant professor. Professors Sartorius Von Waltershansen and Von Seebach lecture each four or five hours weekly on Mineralogy and Geology, and conduct practical demonstrations in the Museums.

In Heidelberg, as in Berlin and Göttingen, and in some respects even in a more perfect measure, large provision is made for the study of physical science. The Physical Laboratory, conducted by Professor Kirchhoff, is very successful. Once weekly Professor Kirchhoff lectures, with experiments, on a given subject; in the following week each student in the laboratory goes. through the experiments for himself, and in this consists the essence of the course. Students can also prosecute independent research for several days in the week.

'The Chemical School of Heidelberg has always been a celebrated one, and since the appointment of Bunsen to the university its renown has greatly increased. In no other European laboratory, with the single exception of that of Liebig at Giessen, have so many promising scientific chemists been trained, and this has been wholly due to the untiring interest shown in each student by the illustrious Professor, who, devoted heart and soul to his science, imparts to his students a portion of that interest in, and zeal for, original investigation, which are the real marks of a scientific spirit. Many of the chemical students at Heidelberg come, as with us, to study the science for the sake of its subsequent applications to manufactures, medicine, or pharmacy (for all the German druggists and pharmaceutical chemists are wisely compelled to attend a regular university course), but many, probably a large fraction of the number, study the science for its own sake, most of these students intending to qualify themselves for the higher posts of scientific instruction in various countries. Amongst the companions of those who studied at Heidelberg with the writer were men who are now making rising reputations in most of the German universities, or in the various institutions of France, Russia, Portugal, Great Britain, and America.

The Physiological Laboratory, conducted by the celebrated philosopher Helmholtz, is a novel and important feature in the Science Department in Heidelberg. A handsome and spacious building has recently been erected for the use of the Professors of Physics and Physiology. This embraces lecture-rooms, laboratories, rooms for apparatus and instruments, and for conducting special scientific investigations, besides dwelling-houses for the professors and their families.

In another article I propose to inquire more closely into the cost of establishing and working the Science Department of the German universities.

HENRY E. ROSCOE

\section{A POINT IN MUSCULAR PHYSICS}

SOME Physiologists abound in statements touching the correlation of forces in living things, and are very fond of repeating the old parallel between a muscle and a steam-engine. We have no desire to deny the aptness of the illustration, but it is as well to bear in mind that, in actual point of fact, the exact correlation of heat and mechanical force has not, as far as muscle is concerned, yet been made fully out. The point of failure is this-suppose we have two muscles: let one muscle when it contracts have to pull against a weight and so produce a decided mechanical effect; let the other muscle have no such weight to pull against, and so in contracting produce no mechanical effect (the trifling weight of the muscle itself we may disregard). According to the doctrine of the correlation of forces, the heat given out in the first case ought to be less than that given out in the second, by reason of the total force produced by the combustion of the muscle going out partly as mechanical force instead of wholly as heat. We suppose of course that exactly same amount of contraction takes place in both cases, and indeed that the muscles are perfectly identical in circumstances, except so far as their load is concerned. Heidenhain some few years ago, however, found out that there was, strange to say, more heat given out in the first case. He also discovered the reason of it, which is that when a muscle is put on the stretch, as, for instance, when a muscle has in contracting to pull against a weight, all the chenical changes in the muscle are augmented, and that roughly in proportion to the amount of strain.

This observation by Heidenhain seems to us one of very far-reaching and often-recurring importance, though apparently it has hardly as yet gained the attention it deserves. At all events it put a stop for a while to any satisfactory settlement of the question we are considering. Quite recently, however, Fick has devised an experiment which seemed to him to avoid the difficulty that had discomfited Heidenhain. The gist of it is simply this. He has two muscles in every way treated alike except in the following point. One muscle he allows to pull a weight up by the force of its contraction, and then lets the weight, when the contraction has passed over, pull the muscle down again. The other muscle pulls up the same weight in the same way, but at the moment that the contraction is at its maximum the weight is slipped off. The muscle then by virtue of its elasticity returns to the length natural to it when unloaded; directly it has reached this point the weight is slipped on again, and the muscle is again ready for a contraction.

It is obvious that in the first case the muscle does no actual work at all; after the contraction the weight undoes what the contraction did. In the second case, on the other hand, the weight is lifted up to a certain point and left there; real work is done.

Such being the case, the temperature of the first muscle ought to rise higher than the second; and when each muscle has been made to contract a good many times this rise ought to be appreciable. Fick finds in fact that it is so. And so we seem here to have what we desired; for both muscles during contraction are subject to the same strain; and hence Heidenhain's objection is obviated. 